\title{
A COMPLEX APPROACH TO STUDY THE AMUR LEOPARD USING CAMERA TRAPS IN PROTECTED AREAS IN THE SOUTHWEST OF PRIMORSKY KRAI (RUSSIAN FAR EAST)
}

\author{
Anna V. Vitkalova, Elena I. Shevtsova \\ United Administration of the State Nature Biosphere Reserve «Kedrovaya Pad» \\ and «Land of the Leopard» National Park, Russia \\ e-mail:vitkalova@leopard-land.ru,shevtsova@leopard-land.ru
}

Received: 20.09.2016

\begin{abstract}
The paper describes the methodology and preliminary results of a complex camera trap study of the Amur leopard. The main studies were concentrated on protected areas: the Land of the Leopard National Park with its buffer zone and the Kedrovaya Pad' Biosphere Reserve, a total area of $3600 \mathrm{~km}^{2}$. The first results of the 2014-2015 survey period are presented. According to spatial capture-recapture analysis at least 57 adult Amur leopards occupied the Russian protected areas with the density of about 0.98 individuals $/ 100 \mathrm{~km}^{2}$. The sex ratio (male : female) was 1:1.2. Five breeding females with 11 cubs were registered in 2014 and 9 females with 16 cubs in 2015. The basis was founded for long-term monitoring of and fundamental research on the Amur leopard in the protected areas in Primorsky Krai.
\end{abstract}

Key words: Amur leopard, camera trap, capture-recapture, Panthera pardus orientalis, Primorsky Krai.

\section{Introduction}

The Amur or Far eastern leopard (Panthera pardus orientalis), one of the rarest large cats in the world, is critically endangered (IUCN Red List; Stein et al., 2016). In Russia the Amur leopard's range is restricted to a small territory of $6500 \mathrm{~km}^{2}$ (Hebblewhite et al., 2011) in the southwest of Primorsky Krai near the state border with China and North Korea. Here the Land of the Leopard National Park was created in 2012 to save these unique felines. Conservation is carried out through direct protection of the territory from poaching and fires, preserving suitable habitats, supporting the population of prey species, ecological education and collaboration with local residents. All these actions require a general knowledge about the biology and ecology of this leopard subspecies. Also regular monitoring of the population is strongly needed for planning and assessment of the efficacy of conservation activities. Therefore, a complex research on the Amur leopard biology and ecology is carried out in the Land of the Leopard National Park.

Camera-trapping is a very effective non-invasive sampling method, especially for rare elusive animals such as leopards (Kostyria et al., 2003; Wang \& Macdonald. 2009; Borah et al., 2013). The range of issues that can be studied with camera trap data include abundance and density, sex and age structure of the population, spatial distribution, territorial use, juvenile dispersion and individual behaviour.
The investigation of the Amur leopard by camera traps in the southwest of Primorsky Krai started in 2003, long before the park was established. It was conducted on two monitoring areas of $700 \mathrm{~km}^{2}$ by the Wildlife Conservation Society Russian Program (WCS-Russia) and the Institute for Sustainable Use of Natural Resources (ISUNR) (Aramilev et al., 2010). But it was only 2014 when a large-scale camera trap survey was initiated which covered more than 50\% of the suitable leopard habitats in Russia. Here we represent the preliminary results of the camera trap study of the Amur leopard in the Land of the Leopard National Park for the period of 2014-2015.

\section{Field work}

\section{Material and Methods}

The study area of $3600 \mathrm{~km}^{2}$ covers the territory of the Kedrovaya Pad' Biosphere Reserve, the Land of the Leopard National Park and its buffer zone - hereafter we will call these two adjacent protected areas as the Land of the Leopard (Fig. 1). In 2014 and 2015 three organizations contributed to the camera trap field work - the Joint Administration of the Land of the Leopard National park and the Kedrovaya Pad' biosphere reserve, the WCS-Russia and the ISUNR.

Digital camera traps equipped with passive infrared motion sensors (Reconyx, Scout Guard, Panthera, Bushnell) were used. The cameras operated both in image and video mode.

Cameras in image mode were installed in pairs for simultaneously taking pictures of both sides of 
the animal, since the leopard's spot pattern is asymmetrical on the right and left flank (Karanth, 1995). Cameras were fixed on trees at a height of $45-50 \mathrm{~cm}$ and the distance to the trail was about 3.5-4.0 m. Camera traps were set on the animal trails on narrow ridges where signs of the leopard presence were found tracks, scrapes, scat. These cameras were used to capture as many leopard individuals in the area as possible to get estimates of abundance, sex and age population structure, as well as spatial distribution.
The camera trap installation scheme represented a $3 \times 3 \mathrm{~km}$ grid with one pair of cameras placed in each cell. The main factor was suitability of the territory for camera trap installation. Any signs of leopard presence, the possibility of camera trap theft and accessibility of the territory were taken into account. This is why some parts of the national park such as unforested areas, remote areas of Borisovskoe Plateau and areas closed to villages were not included in the study site.

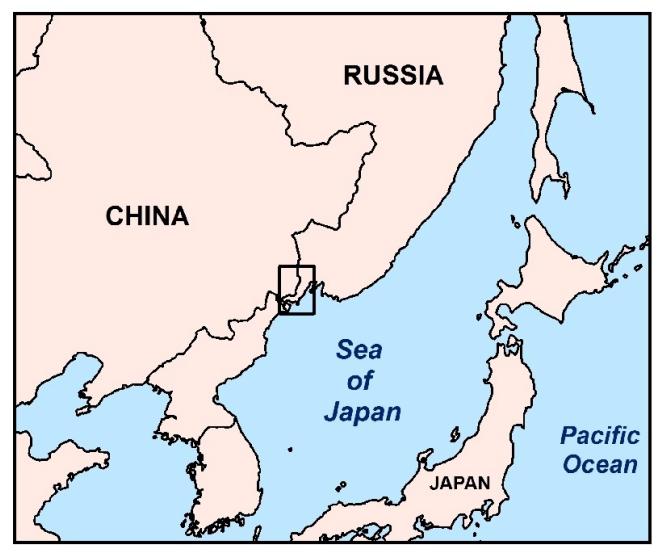

- Camera trap locations in 2015

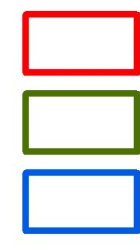

Kedrovaya Pad' Bioshere Reserve

Land of the Leopard National Park

National Park buffer zone

Effective trapping area in 2015

State border

- Fence
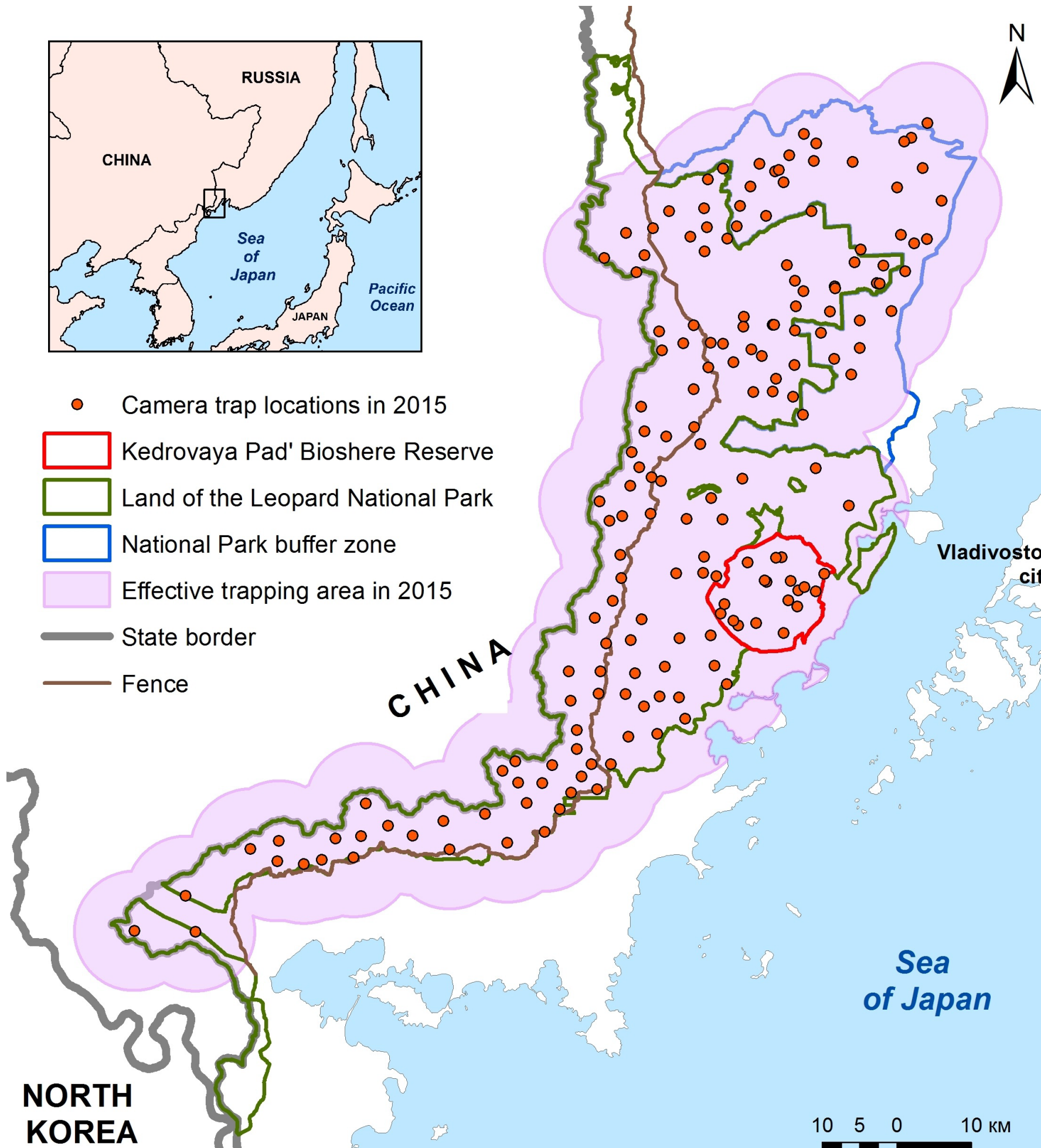

$\mathrm{N}$

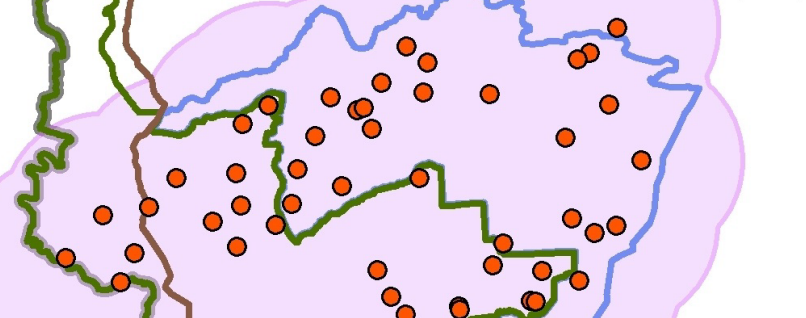

a 8
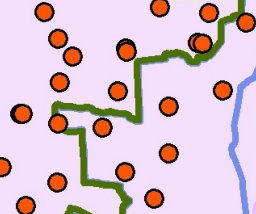

이잉
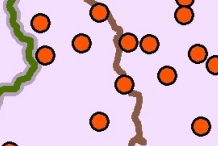

$0 \log _{0}^{0}$
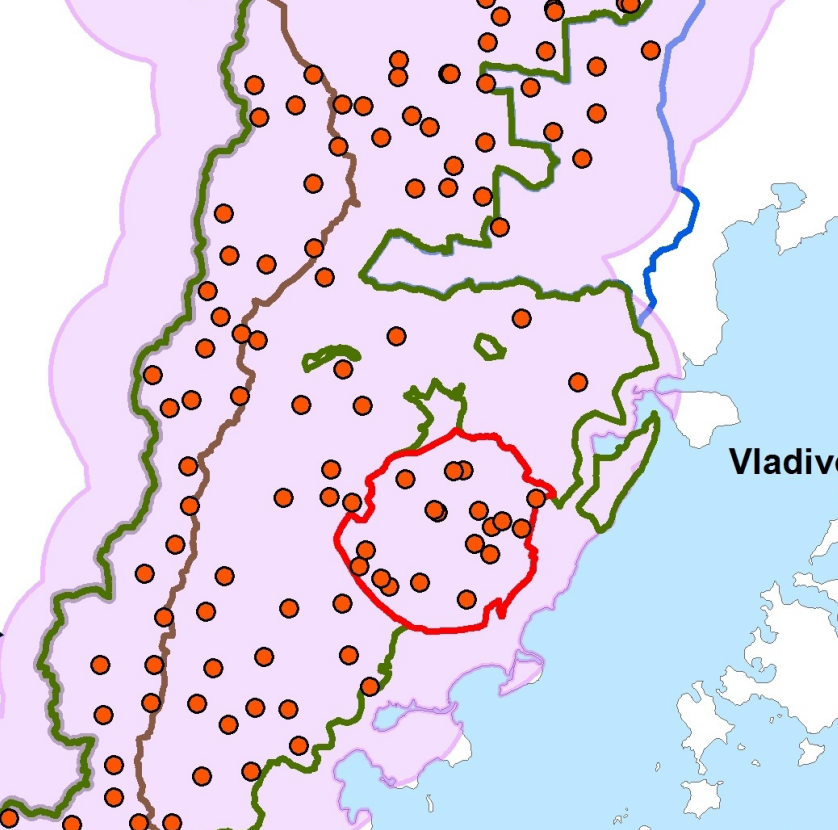

Vladivostok city

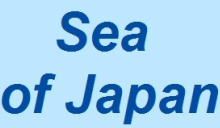

1050

$10 \mathrm{KM}$

Fig. 1. Study area and camera trap locations in 2015. 
In previous studies in the southwest of Prymorskii Krai cameras were installed in February-March and uninstalled in May-June to ensure that cameras operate at least for 3 months (Kostyria et al., 2006). In our survey the study area was divided into two parts by a fence that runs parallel to the international border at a distance of 5-20 km from the state border. The cameras operated in two different modes. Camera traps installed beyond the fence operated constantly. Memory cards and batteries were checked twice a year. Camera traps installed before the fence operated from late winter till the beginning of summer. Camera trap locations were entered into a GIS database with ArcGis 10.3 software. The same software was used for spatial data analysis.

According to this survey design we obtained information from the territory of the national park and the reserve for the period of 3 months, which is sufficient for capture and recapture analysis to reveal abundance and densities. This is the so-called «survey period». Data from camera traps installed beyond the border fence (which operate constantly) give us additional information about individuals living in the territory close to the international border, which allows us for investigation of seasonal changes and monitoring the migration of animal through the state border. This period, including summer, autumn and early winter, is the so-called «out-of-survey period».

The effective trapping area was estimated by projecting a buffer around each camera trap location. The buffer size was equal to a mean Amur leopard home range radius and was set to $8 \mathrm{~km}$ (Salmanova, 2012). The effective trapping area was 5146 and $5548 \mathrm{~km}^{2}$ in 2014 and 2015 (Fig. 1).

Cameras in video mode were installed in places where specific activity could be recorded - near marking trees, in front of rocks and small caves which can serve as a den. This video was used for behavioural studies.

\section{Images and video processing, individual identification}

The unit of information in the camera trap data is the «encounter». This is an event when an individual or group of individuals was «captured» by a camera trap in a given location at a certain time. The information about all leopard encounters was entered into a Microsoft Access 2010 database: date, time, location co-ordinates, the images of left and right flank of each animal. Individual identification was made with ExtractCompare software (http://conservationresearch.org.uk/). This software uses the standard algorithm to compare hundreds of images and offer to a researcher a list of possible matches to choose from (Hiby et al., 2009). ExtractCompare does not give an answer whether these two images belong to a single animal. For each new image the program chooses the similar spot pattern from the existing database and offers it to a researcher for confirmation. The researcher compares visually the spot pattern and confirms the match or confirms that this image belongs to another animal.

After individual identification a photo database and encounter history for each leopard were developed. Sex was determined visually by the presence/ absence of testes and cubs. Each individual was assigned a unique ID, consisting of a number and sex index. Finally the result of the camera trap data processing was the information about each leopard encounter - animal ID, location, date/time.

\section{Abundance and density estimation}

The camera trap data allows individual identification by spot pattern. Thus it is spatially linked information about each individual. The simple counting of the identified individuals reveals the minimum number of leopards. To get a statistical assessment of the abundance and density «capturerecapture» analysis is applied.

In this study the SPACECAP package (Gopalaswamy et al., 2012) ver. 1.0.1 (Gopalaswamy et al., 2014) in R environmental was used to obtain abundance and density estimates. The study period was divided into a series of occasions (each equal to one day) and encounter history for each individual was created, indicating the number of occasions and the name of the camera trap location where the animal was captured. Trap response behaviour was set to «absent» and detection function to «half-normal». Five-fold data augmentation was used and 50000 iterations were carried out.

\section{Results and Discussion \\ Abundance and density}

The Amur leopard abundance and density in protected areas and in its general range is a research issue of great interest. Population numbers are currently so low - no more than 50 individuals according to the last survey (Aramilev V.V. \& Aramilev S.V., 2013) - that any sustained decrease would become critical for survival and would necessitate direct intervention. So abundance and density are parameters that should be monitored annually.

7568 Images and about 50 hours of video of the Amur leopard were obtained by camera traps during the 2014-2015 study period. We identified 83 adult individuals and 21 cubs, in total 104 animals. Here we distinguish cubs as individuals captured together with a female, regardless of their age, and never captured alone. These animals are not assigned an ID 
until they are captured as a single individual, since the likelihood of mortality is quite high; besides young leopards actively disperse to other territories. The number of individuals known only as cubs is very high because 16 cubs were captured during 2015 and we do not yet know their fate. A Microsoft database was formed which contains the information about 1141 leopard encounters including date, time, camera trap location. Table 1 summarises the amount of data obtained during 2 years of study.

The numbers summarised in Table 1 are not real population abundance estimates, since the population cannot be considered as closed during such a long period. These figures merely demonstrate the number of animals which used the study area during the year. To produce an estimate of abundance we used the data from a 90-day period when a greater part of the camera traps were operational. 48 Adult leopard individuals and 3 cubs were identified in 2014, 47 adult individuals and 8 cubs in 2015.

A spatial explicit capture-recapture analysis was made with the SPACECAP package in R. Only adult individuals were included in the analysis. All the leopards captured with their mother were considered being cubs. The resulted abundance and density estimates are presented in Table 2.

Table 1. The summary of camera trap data obtained in 2014-2015 in Land of the Leopard

\begin{tabular}{|l|c|c|}
\hline & 2014 & 2015 \\
\hline Number of cameras installed & 143 & 170 \\
\hline Effective trapping area $\left(\mathrm{km}^{2}\right)$ & 5146 & 5548 \\
\hline Proportion of cameras with leopard encounters, $\%$ & 74.8 & 68.2 \\
\hline Number of Amur leopard encounters & 617 & 524 \\
\hline Number of individually recognized leopards (totally) & 79 & 74 \\
\hline Adults only & 68 & 58 \\
\hline Males & 28 & 22 \\
\hline Females with cubs & 5 & 9 \\
\hline Females without cubs & 33 & 24 \\
\hline Unknown sex individuals & 2 & 3 \\
\hline Cubs & 11 & 16 \\
\hline
\end{tabular}

Table 2. Minimal number of Amur leopard individuals, abundance and density estimates from camera trap data in the Land of the Leopard

\begin{tabular}{|l|c|c|}
\hline & 2014 & 2015 \\
\hline Survey period & $03.03 .2014-31.05 .2014$ & $16.01 .2015-15.04 .2015$ \\
\hline Number of individuals captured in survey period (totally): & 51 & 55 \\
\hline Adults only & 48 & 47 \\
\hline Males & 21 & 20 \\
\hline Females with cubs & 24 & 4 \\
\hline Females without cubs & 2 & 3 \\
\hline Unknown sex individuals & 1 & 8 \\
\hline Cubs & 3 & $57.2 \pm 3.5$ \\
\hline SPACECAP abundance estimate & & $51-64$ \\
\hline Mean \pm SD & $57.4 \pm 3.8$ & \\
\hline $95 \%$ CI & $51-65$ & $0.98 \pm 0.061$ \\
\hline SPACECAP density estimate (individuals $/ 100 \mathrm{~km}^{2}$ ) & & $0.87-1.09$ \\
\hline Mean \pm SD & $0.98 \pm 0,064$ & $0.87-1.1$ \\
\hline $95 \%$ CI & & \\
\hline
\end{tabular}

\section{Sex structure of population}

Sufficiently precise identification of sex by images is mostly possible. Only cub presence is an unambiguous indicator that the individual is a female and only the presence of testes confirms that it is a male. But thanks to the database of identified individuals we are able to know that an individual is male or female even when these indicators are not present.

Camera trap data analysis for 2014-2015 resulted only in 2 and $6 \%$ of individuals being of unknown sex, respectively. The sex ratio (male to female) was 1:1.24 and 1:1.2 in 2014 and 2015 respectively.

\section{Reproduction estimates}

27 Cubs of 14 females were captured during the 2014-2015 study period. One cub was captured without a mother. The number of cub in the litter varied from 1 to 3 .

The enlarged study area, number of camera trap locations and prolonged sampling period in- 
creased the probability of capturing females with cubs. The camera trap functioning has also been much improved. Nowadays, digital cameras allow taking images continuously without breaks, which significantly decreases the chance to miss a cub. But females with cubs are especially secretive, and so litter capture is still very difficult. More than half of the encounters with cubs happened out of the survey period. So the number of captured cubs is not the true number of newborn cats.

Nine individuals were captured alone after a litter break-up. But more long-term monitoring is needed to make inferences about cub survival rates. Also, further investigation is planned into the dispersion of young individuals.

\section{Spatial distribution and territory use}

Spatial information about individual location and movements obtained with camera traps is limited. We can only approximately infer the territory that a leopard uses. But we are able to obtain data about a large number of individuals without their physical capture. Our preliminary data confirm that individual home ranges highly overlap. But more information is needed to complete the analysis since only resident individuals should be included in the analysis.

Amur leopards are solitary and each individual has a large home range of about $80-300 \mathrm{~km}^{2}$ (Salmanova, 2012). This means that individuals registered by our camera traps likely use a territory extending far beyond the study area. The territory of Land of the Leopard National Park is located along the international border with China. More than half of the camera traps are installed in the border zone, some of them not more than $500 \mathrm{~m}$ from the border. Thus, the effective trapping area extends deep into Chinese territory. In recent years the presence of leopards and even breeding females has been confirmed in China and the number of individuals seems to show a positive trend (Wang et al., 2015). In 201426 individual adult leopards were recorded in China during the March-June survey period (Wang et al., 2016). At the same time 47 individuals were registered in Russia. It is obvious that part of these animals have their home ranges both in Russia and China. Only joint analysis of data can give a global Amur leopard abundance estimate. This highlights the importance of international co-operation and joint cross-boundary research.

\section{Behavioural studies}

Besides camera traps in photo mode installed in a regular grid, some cameras are installed in video mode in such places as small caves, rocks and in front of marking trees. This video data is used for behaviour analysis - social, sexual, paternal. The time slicing method was used, in which animal activity is registered at regular time intervals of about 10 seconds for analysis.

In 2013 these cameras captured a female with 3 cubs in the Kedrovaya Pad reserve. This leopard family was successfully observed for three months in the winter of 2013-2014 before the litter broke up. These data are being processed and analysed now. Later one of the cubs, which turned out to be a female, was captured at the same place in 2015. It seems that this female has occupied the home range of her mother and video traps installed in the Kedrovaya Pad Biosphere Reserve continue to record not only her presence, but also some secret details of her behaviour and communication with other individuals.

\section{Conclusions}

The data represented in the paper above describe the methodology and the first results of a large-scale camera trap survey of the Amur leopard within its Russian range. It should be emphasised that most of these results are only preliminary. But it is clear that the established network of camera traps is an effective tool for Amur leopard monitoring and study.

\section{Acknowledgements}

We sincerely thank the staff of the Land of the Leopard National Park for the hard field work: Victor B. Storozhuk, Dina S. Matyukhina, Anton P. Ganzevich, Nikolay E. Petrov, employees of the Law enforcement department. We also thank the Wildlife Conservation Society and the Institute for Sustainable Use of Natural Resources for contribution in field work, data collection and processing, consultation: Dale G. Miquelle, Alexander N. Rybin, Vladimir V. Aramilev, Sergei A. Sokolov. This work was supported by the Autonomous Non-profit Organization "Far Eastern Leopards" and the Russian Geographical Society.

\section{References}

Aramilev V.V., Kostyria A.V., Sokolov S.A., Rybin A.N., McCullough D., Miquelle D. 2010. Monitoring of Far eastern leopard population (Panthera pardus orientalis) with photo traps. In: Proceedings of International Conference "The Amur Tiger in Northeast Asia: Planning for the 21st Century». Vladivostok. P. 345-351.

Aramilev V.V., Aramilev C.D. 2013. Report on Amur leopard snow survey. Vladivostok. 14 p. [In Russian]

Borah J., Sharma T., Das D., Rabha N., Kakati N., Basumatary A., Ahmed M.F., Vattakaven J. 2014. Abundance and density estimates for common leopard Panthera pardus and clouded leopard Neofelis nebulosa in Manas National Park, Assam, India. Oryx 48: 149-155.

Gopalaswamy A.M., Royle J.A., Hines J.E., Sing P., Jathanna D., Kumar N.S., Karanth K.U. 2012. Program SPACECAP: software for estimating animal density using spa- 
tially explicit capture-recapture models. Methods in Ecology and Evolution 3 (6): 1067-1072.

Gopalaswamy A.M., Royle J.A., Meredith M.E., Sing P., Jathanna D., Kumar N.S., Karanth K.U. 2014. SPACECAP: An R package for estimating animal density using spatially explicit capture-recapture models. Wildlife Conservation Society - India Program, Centre for Wildlife Studies, Bengaluru, India. Version 1.1.0.

Hebblewhite M., Miquelle D.G., Murzin A.A., Aramilev V.V., Pikunov D.G., 2011. Predicting potential habitat and population size for reintroduction of the Far Eastern leopards in the Russian Far East. Biological Conservation 144: 2403-2413.

Hiby L., Lovell P., Patil N., Kumar N.S., Gopalaswamy A.M., Karanth K.U. 2009. A tiger cannot change its stripes: using a three-dimensional model tomatch images of living tigers and tiger skins. Biology letters 5 (3): 383-386.

Karanth K.U. 1995. Estimating tiger populations from cameratrap data using capture-recapture models. Biological Conservation 71: 333-338.

Kostyria A.V., Skorodelov A.S., Miquelle D.G., Aramilev V.V., McCullough D. 2003. Results of camera trap survey in Far Eastern leopard population in southwest Primorski Krai, winter 2002-2003. Report of the Wildlife Conservation Society and Institute of Sustainable Use of Nature Resources. Vladivostok. 23 p. [In Russian]

Kostyria A.V., Skorodelov A.S., Miquelle D.G., Aramilev V.V., Rybin A.N. 2006. Results of 6camera trap survey in Far Eastern leopard population in southwest Primor- ski Krai, winter 2006. Report of the Wildlife Conservation Society and Institute of Sustainable Use of Nature Resources. Vladivostok. 33 p. [In Russian]

Salmanova E. 2012. Amur leopard home range. In: Student conference on conservation science. UK, Cambridge: Cambridge university press. P. 42.

Stein A.B., Athreya V., Gerngross P., Balme G., Henschel P., Karanth U., Miquelle D., Rostro S., Kamler J.F., Laguardia A. 2016. Panthera pardus. The IUCN Red List of Threatened Species 2016 : e.T15954A50659089. http://dx.doi.org/10.2305/IUCN.UK.2016-1.RLTS. T15954A50659089.en.

Wang S.W., Macdonald D.W. 2009. The use of camera traps for estimating tiger and leopard populations in the high altitude mountains of Bhutan. Biological Conservation 142 (3): 606-613.

Wang T.M., Feng L.M., Mou, P. Wu, J.G., Smith J.L.D., Xiao W.H., Yang H.T., Dou H.L., Zhao, X.D. Cheng, Y.C., Zhou B., Wu H.Y., Zhang L., Tian Y., Guo Q.X., Kou X.J., Han X.M., Miquelle D.G., Oliver C.D., Xu R.M., Ge J.P. 2015. Amur tigers and leopards returning to China: direct evidence and a landscape conservation plan. Landscape Ecology 31 (3): 491-503.

Wang, T., Feng L., Yang H., Hana B., Zhao Y., Juana L., Lüa X., Zou L., Li T., Xiao W., Mou P., Smith J.L.D., Ge J. 2016. A science-based approach to guide Amur leopard recovery in China. Biological Conservation. doi: 10.1016/j.biocon.2016.03.014

\title{
КОМПЛЕКСНЫЙ ПОДХОД В ИЗУЧЕНИИ ДАЛЬНЕВОСТОЧНОГО ЛЕОПАРДА ПРИ ПОМОЩИ ФОТОЛОВУШЕК НА ОСОБО ОХРАНЯЕМЫХ ПРИРОДНЫХ ТЕРРИТОРИЯХ ЮГО-ЗАПАДА ПРИМОРСКОГО КРАЯ РОССИЙСКОГО ДАЛЬНЕГО ВОСТОКА
}

\author{
А. В. Виткалова, Е. И. Шевцова \\ Объединенная дирекиия Государственного природного биосферного заповедника \\ «Кедровая падь» и наиионального парка «Земля леопарда», Россия \\ e-mail:vitkalova@leopard-land.ru,shevtsova@leopard-land.ru
}

\begin{abstract}
В статье представлены методика и предварительные результаты комплексного исследования дальневосточного леопарда при помощи фотоловушек. Исследования проводились на особо охраняемых природных территориях - в национальном парке «Земля леопарда», включая его буферную зону, и в биосферном заповеднике «Кедровая падь», общей площадью 3600 км². Согласно данным, полученным за период 2014-2015 гг., по результатам пространственного анализа методом повторного отлова 57 взрослых особей дальневосточного леопарда населяли российские ООПТ со средней плотностью 0.98 особей/100км². Количественное соотношение самцов к самкам составило 1:1.2. В течение 2014 г. зафиксировано 5 самок и 11 котят, в 2015 г. - 9 самок и 16 котят. Заложена основа для долговременного мониторинга и фундаментального изучения популяции дальневосточного леопарда на особо охраняемых природных территориях Приморского края.
\end{abstract}

Ключевые слова: Panthera pardus orientalis, дальневосточный леопард, Приморский край, повторный отлов, фотоловушка. 